\title{
EFEKTIFITAS METODE PEMBELAJARAN SNOWBALL THROWING TERHADAP HASIL BELAJAR MATEMATIKA SISWA KELAS VII SEMESTER GENAP MTS AL ROSYID TAHUN PELAJARAN 2015-2016
}

\author{
Nur Rohman \\ Jurusan Pendidikan Matematika IKIP PGRI Bojonegoro \\ e-mail: nurrohmanspd83@yahoo.co.id
}

\begin{abstract}
Abstrak
Tujuan dari penelitian ini adalah untuk mengetahui pengaruh metode pembelajaran Snowball Throwing dibandingkan dengan metode ceramah terhadap prestasi belajar matematika siswa. Desain penelitian ini adalah penelitian eksperimental semu. Populasi dalam penelitian ini adalah siswa kelas tujuh di Mts Al Rosyid Kendal Bojonegoro pada tahun akademik 2015/2016. Teknik analisis data yang digunakan adalah uji normalitas dan homogenitas metode bartlett dengan tingkat signifikan 0,05. uji keseimbangan menggunakan analisis varians satu jalan. Pengujian hipotesis Teknik yang digunakan t-test, rumus Varians yang Terpisah. Dari hasil tersebut, peneliti menyimpulkan bahwa metode Snowball Throwing memberikan pengaruh yang signifikan terhadap prestasi belajar matematika pada materi segitiga siswa kelas tujuh di MTS Al Rosyid Kendal Bojonegoro pada tahun akademik 2015-2016.
\end{abstract}

Kata Kunci: Snowball Throwing, Ceramah, Hasil Belajar Matematika

\section{PENDAHULUAN}

Sebagian peserta didik menganggap matematika sulit, terlebih lagi sebagai mata pelajaran dengan konsep-konsep yang abstrak menyebabkan mereka semakin kesulitan dalam memahaminya, akibatnya prestasi belajar yang dicapai masih tergolong rendah. Pembaharuan kurikulum tidak akan banyak berarti jika tidak terjadi perubahan praktik pembelajaran dikelas. Dalam hal ini guru diharapkan dapat melakukan inovasi dalam pemilihan pendekatan serta metode pembelajaran yang tepat. Di dalam Kurikulum Tingkat Satuan Pendidikan (KTSP) fokus pembelajaran matematika hendaknya pendekatan pemecahan masalah. Masalah tersebut mencakup masalah tertutup dengan solusi tunggal, masalah terbuka dengan solusi tidak tunggal, dan masalah dengan berbagai cara penyelesaian (Permendiknas, 2006).

Pelajaran matematika dipandang sebagai bagian ilmu-ilmu dasar yang berkembang pesat baik isi-isi maupun aplikasinya serta dapat menumbuhkan kemampuan siswa untuk berpikir kritis, sistematis, logis kreatif dan kemampuan bekerja sama yang efektif (Depdiknas, 2004). Matematika juga sebagai ilmu dasar yang mempunyai peran penting dalam upaya penguasaan ilmu dan teknologi. Ini berarti bahwa matematika perlu dikuasai oleh semua warga negara Indonesia, baik penerapannya maupun pola pikirnya. Namun 
demikian hingga saat ini hasil belajar matematika masih belum memuaskan. Salah satu bukti belum memuaskannya hasil belajar matematika ditemukan oleh peneliti di MTs Al-Rosyid sewaktu mengadakan wawancara dengan guru matematika kelas VII. Diperoleh informasi dari pengamatan guru bahwa selama proses pembelajaran siswa cenderung kurang termotivasi dan hanya menerima informasi dari guru, terutama pada pokok bahasan yang menyajikan konsep-konsep yang bersifat abstrak dan sulit, misalnya pada pokok bahasan segitiga. Pokok bahasan segitiga merupakan pokok bahasan hafalan dan perhitungan yang menyajikan konsep-konsep. Hal ini menyebabkan siswa kurang termotivasi untuk aktif mencari informasi sendiri dan menerapkan pengetahuannya. Data MTs Al-Rosyid menunjukkan bahwa nilai rata-rata kelas VII tahun pelajaran 2015-2016 mata pelajaran matematika pada pokok bahasan segitiga adalah 5,22 sehingga dapat disimpulkan bahwa hasil belajar matematika pada pokok bahasan segitiga belum memuaskan.

Selain bersumber dari kemampuan siswanya, kegagalan guru dalam menyampaikan materi disebabkan saat proses belajar mengajar guru kurang membangkitkan perhatian dan aktivitas. Pembelajaran di kelas didominasi oleh pemahaman strukturalis yang bertujuan siswa mengingat informasi lalu terjadi memorasi sehingga hasil belajar matematika yang diperoleh belum memuaskan (Hamdayama: 2014).

Salah satu alternative untuk mengatasi permasalahan di atas adalah penggunaan metode pembelajaran aktif. Menurut Siporin (Siporin, 1975), metode adalah sebuah orientasi aktifitas yang mengarah kepada persyaratan tugas-tugas dan tujuan nyata. Sedangkan menurut Ruslan (2003:24) metode merupakan kegiatan ilmiah yang berkaitan dengan suatu cara kerja sistematis untuk memahami suatu subjek atau objek penelitian, sebagai upaya untuk menemukan jawaban yang dapat dipertanggung jawabkan secara ilmiah termasuk keabsahannya.

Selanjutnya menurut Suprijono (2014) pembelajaran aktif adalah proses belajar yang menumbuhkan dinamika belajar bagi peserta didik. Dinamika untuk mengartikulasikan dunia idenya dan mengkonfrontir ide itu dengan dunia realitas yang dihadapinya. Metode pembelajaran aktif yang tepat untuk mengatasi permasalahan tersebut yaitu metode pembelajaran snowball throwing.

Menurut Hamdayama (Hamdayama, 2014) metode pembelajaran Snowball Throwing merupakan suatu metode pembelajaran yang menggunakan tiga penerapan pembelajaran yaitu pengetahuan dibangun sedikit demi sedikit yang hasilnya diperluas melalui konteks yang terbatas melalui pengalaman nyata (constructivism), pengetahuan dan ketrampilan yang diperoleh siswa diharapkan bukan hasil mengingat seperangkat fakta-fakta tetapi hasil dari menemukan sendiri (inquiry), pengetahuan yang dimiliki seseorang selalu bermula dari "bertanya" (questioning), dari bertanya siswa dapat menggali informasi, mengkonfirmasikan apa yang sudah diketahui dan mengarahkan perhatian pada aspek yang belum diketahui.

Menurut Suprijono (Suprijono, 2014) metode pembelajaran Snowball Throwing merupakan suatu metode pembelajaran yang diawali dengan pembentukan kelompok yang 
diwakili ketua kelompok untuk mendapat tugas dari guru, kemudian masing-masing siswa membuat pertanyaan pada selembar kertas yang dibentuk seperti bola lalu dilempar ke siswa lain yang masing-masing siswa menjawab pertanyaan dari bola yang diperoleh. Sedangkan menurut (Asrori,2010) metode pembelajaran Snowball Trowing merupakan suatu metode pembelajaran aktif yang dalam pelaksanaannya banyak melibatkan siswa. Peran guru hanya sebagai pemberi arahan awal mengenai topik pembelajaran dan selanjutnya penertiban terhadap jalannya pembelajaran.

Tujuan penelitian ini adalah untuk mengetahui: 1) Apakah ada pengaruh metode pembelajaran Snowball Throwing terhadap hasil belajar matematika pada pokok bahasan segitiga siswa kelas VII semester genap MTs Al Rosyid tahun pelajaran 2015-2016?

\section{METODE}

Waktu penelitian dilaksanakan pada semester genap tahun ajaran 2015/2016. Untuk mengetahui pengaruh metode pembelajaran Snowball Throwing terhadap hasil belajar matematika siswa. Populasi dalam penelitian ini adalah semua siswa kelas VII Mts Al Rosyid Kendal Bojonegoro tahun ajaran 2015/2016. Jumlah siswa kelas VII Mts Al Rosyid Kendal Bojonegoro tahun ajaran 2014/2015 adalah sebanyak 123 siswa yang terbagi menjadi 4 kelas, dengan rincian kelas VIIa terdiri dari 31 siswa, VIIb terdiri dari 30 siswa, VIIc terdiri dari 30 siswa dan VIId terdiri dari 32 siswa. Berdasarkan hasil cluster random sampling, kelas yang menjadi sampel dalam penelitian adalah kelas VIIa sebagai kelas eksperimen dan kelas VIIc sebagai kelas kontrol.

Teknik analisis data dalam penelitian ini menggunakan Teknik analisis data dalam penelitian ini adalah teknik statistik dengan uji t komparatif independen yaitu dengan menggunakan rumus separated Varians (Sugiyono, 2007). Uji prasyarat yang dipakai dalam analisis data penelitian adalah uji normalitas dengan metode Lilliefors dan uji homogenitas dengan metode Bartleet. (Budiyono, 2009)

\section{HASIL}

Uji coba instrumen dilakukan pada kelas VIIIa. Hasil uji coba menunjukkan bahwa instrumen penelitian yaitu soal tes prestasi belajar matematika adalah baik sehingga dapat digunakan dalam penelitian. Data kemampuan awal yaitu data dari nilai UAS semester ganjil digunakan untuk uji keseimbangan.Uji t digunakan untuk uji keseimbangan dengan prasyarat populasi normal dan homogen.

Hasil uji normalitas berdasarkan uji normalitas keadaan awal kelas eksperimen diperoleh $\mathrm{L}^{\text {hitung }}=0,1537377$ dengan $\alpha=0,05$ maka diperoleh $\mathrm{L}_{(0,05 ; 30)}=$; $D K=\{L / L>0,158109\} ; L_{o b s}=0,1537377 \notin D K$. Jadi, $\mathrm{H}_{0}$ diterima artinya sampel berasal dari populasi berdistribusi normal. Sedangkan pada kelas kontrol diperoleh $\mathrm{L}_{\text {hitung }}=$ 0,13742442 dengan $\alpha=0,05$ maka diperoleh $\mathrm{L}_{(0.05 ; 30)}=$; 
$D K=\{L / L>0,158109\} ; L_{o b s}=0,13742442 \notin D K$ Jadi, $\mathrm{H}_{0}$ diterima artinya sampel berasal dari populasi yang normal. Hasil uji homogenitas kelas eksperimen dan kelas kontrol berdasarkan keadaan awal antara kelas eksperimen dan kelas kontrol diperoleh $x^{2}{ }_{\text {obs }}=0,075605$ dengan $\alpha=0,05$ maka diperoleh $x_{0,05 ; 1}^{2}=3,841 ; \quad \mathrm{DK}=$ $\left\{x^{2} \mid x^{2}>3,841\right\}, x^{2}{ }_{o b s}=0,075605 \notin D K$. Jadi, $\mathrm{H}_{0}$ diterima artinya sampel berasal dari populasi yang homogen.

Setelah dilakukan uji normalitas dan uji homogenitas, selanjutnya dilakukan uji keseimbanga. Berikut tabel uji rangkuman hasil uji keseimbangan.

Tabel 1: Rangkuman Hasil Uji keseimbangan

\begin{tabular}{|c|c|c|c|}
\hline Kelompok & $\mathbf{t}_{\text {obs }}$ & $\mathbf{t}_{\text {tabel }}$ & Kesimpulan \\
\hline $\begin{array}{c}\text { Kelas Eksperimen dan } \\
\text { Kelas Kontrol }\end{array}$ & 0,4484 & 2,002 & $\mathrm{H}_{0}$ ditolak \\
\hline
\end{tabular}

Berdasarkan tabel 1. Hasil uji keseimbangan antara populasi pembelajaran Snowball Throwing, dan Ekspositori diperoleh $\mathrm{F}_{\mathrm{obs}}=0,4484<\mathrm{F}_{\mathrm{tab}}=2,002$ sehingga Ho diterima, berarti kedua populasi dalam keadaan seimbang.

\section{PEMBAHASAN}

Analisis data awal dilaksanakan sebelum dilakukan eksperimen. Untuk menguji keseimbangan dua sampel penelitian menggunakan uji $\mathrm{t}$, dengan $\alpha=5 \%, \mathrm{dk}=58 ; \mathrm{t}_{\text {tabel }}=$ 2,$002 ; t_{\text {hitung }}=-0,448$. karena $t_{\text {tabel }} \geq t_{\text {hitung }}$ maka dapat kesimpulan bahwa kedua kelompok tersebut mempunyai kemampuan yang sama (seimbang). Setelah kedua kelas dinyatakan seimbang, langkah selanjutnya adalah analisis butir soal dengan validitas isi, daya beda, tingkat kesukaran, dan reliabilitas (Suharsimi Arikunto, 2007:58). Instrumen penelitian berupa tes berbentuk soal pilihan ganda sebanyak 25 butir soal pilihan ganda. Validasi butir soal dilakukan oleh tiga orang pakar matematika yaitu Dra. Junarti, M.Pd, Drs. Sujiran,M.Pd dan Mafi Laili Rosyida,S.Pd. Setelah 25 butir soal dinyatakan valid, kemudian soal tersebut di uji cobakan pada tanggal 12 Maret 2016 di kelas VIII-A yang pernah mendapatkan pelajaran tersebut.

Hasil analisis menyatakan pada uji validitas diperoleh 21 soal dinyatakan valid dan 4 soal dinyatakan tidak valid. Pada uji reliabilitas semua butir soal (25 soal) dinyatakan reliabel. Untuk daya beda diperoleh 2 soal dinyatakan jelek, 3 soal dinyatakan cukup, 19 soal dinyatakan baik dan 1 soal dinyatakan sangat baik. Sedangkan untuk tingkat kesukaran diperoleh 7 soal mudah, 13 soal sedang dan 5 soal sulit.

Setelah dilakukan analisis diatas maka kelas eksperimen diberi perlakuan dengan menggunakan metode pembelajaran Snowball Throwing sedangkan kelas kontrol menggunakan metode ceramah. Menurut (Suprijono ,2014: 105) keunggulan metode pembelajaran Snowball Throwing adalah optimalisasi partisipasi siswa dan materi dalam 
proses pembelajaran. Pada tahap berpikir bersama, siswa diberi kebebasan untuk menjelaskan materi melalui diskusi dengan kelompoknya dan saling bertanya tentang materi yang sedang dibahas, sehingga siswa merasa senang dan termotivasi untuk mengikuti pembelajaran. Kegiatan membuat soal mandiri pada selembar kertas, kemudian meremasnya menjadi bola kecil akan memudahkan siswa untuk memahami dan mengingat kembali apa yang telah dipelajari. Kegiatan melempar bola pertanyaan pada teman akan menumbuhkan rasa tanggung jawab dan memotivasi siswa untuk lebih giat belajar.

Sedangkan pembelajaran yang dilaksanakan pada kelas kontrol adalah pembelajaran dengan menggunakan metode ceramah. Menurut Hamdayama (2014) kelebihan dari metode ceramah adalah guru lebih mudah menerangkan bahan pelajaran berjumlah besar, lebih hemat waktu dan biaya, dapat diterapkan pada kelas dengan kemampuan siswa yang heterogen. Namun dalam penerapan proses pembelajaran, metode ceramah juga memiliki beberapa kekurangan diantaranya kegiatan pengajaran menjadi verbalisme (pengertian kata-kata), siswa yang lebih tanggap dari sisi visual akan menjadi rugi dan siswa yang lebih tanggap auditifnya dapat lebih besar menerimanya, sukar mengontrol sejauh mana perolehan belajar, cepat membosankan dan menyebabkan siswa pasif dalam pembelajaran.

Setelah kelas eksperimen dan kelas kontrol mendapat perlakuan yang berbeda, kemudian kedua kelompok diberi tes hasil belajar. Hasil dari tes hasil belajar kedua kelompok dilakukan uji normalitas, uji homogenitas, dan uji hipotesis. Uji normalitas dilakukan dengan menggunakan uji liliefors yang dilakukan pada kedua kelas. Pada kelas eksperimen (KelasVII-A) didapat rata-rata 80,66, standart deviasi $=12,5075$, taraf signifikan $(5 \%)$ maka harga $\mathrm{L}_{\text {observasi }}=0,1282$, dan $\mathrm{L}_{\text {tabel }}=0,1581\left(\mathrm{~L}_{\text {tabel }} \geq \mathrm{L}_{\text {hitung }}\right)$. Sehingga dapat disimpulkan sampel tersebut berdistribusi normal. Sedang pada kelas kontrol (KelasVII-C) didapat rata-rata 64,50, standart deviasi $=8,0248$, taraf signifikan $(5 \%)$ maka harga $\mathrm{L}_{\text {observasi }}$ $=0,1466$, dan $\mathrm{L}_{\text {tabel }}=0,1581\left(\mathrm{~L}_{\text {tabel }} \geq \mathrm{L}_{\text {hitung }}\right)$. Sehingga dapat disimpulkan sampel tersebut berdistribusi normal.

Uji homogenitas digunakan sebagai prasyarat uji t-tes apabila data yang dibandingkan berdistribusi normal. Uji homogenitas dilakukan dengan menggunakan uji Bartlet. Dengan taraf signifikan $=5 \%,{ }_{\text {tabel }}=3,8410$, dan ${ }^{2}$ hitung $=\left({ }^{2}\right.$ tabel $\geq{ }^{2}$ hitung). Sehingga dapat disimpulkan bahwa kedua kelas tersebut homogen.

Berdasarkan uji hipotesis penelitian yang telah dilaksanakan dengan menggunakan uji-t didapat nilai $t_{\text {tabel }}=2,002$ dengan taraf signifikan $5 \%$ dan dk 58 sedangkan $t_{\text {hitung }}=$ 2,2584 karena $t_{\text {hitung }}>\mathrm{t}_{\text {tabel }}$ maka ditolak yang berarti ada pengaruh metode pembelajaran Snowball Throwing terhadap hasil belajar matematika pada pokok bahasan segitiga siswa kelas VII semester genap MTs Al Rosyid tahun pelajaran 2015-2016.

Hal ini sesuai dengan penelitian yang dilakukan oleh Luh Sunistini Margunayasa dengan judul "Penerapan Metode Snowball Throwing Berbantuan Media Sederhana untuk Meningkatkan Hasil Belajar Matematika Siswa SD Negeri 1 Petandakan”. Hasil penelitian tersebut menyatakan bahwa penerapan metode Snowball Throwing berbantuan media sederhana dapat meningkatkan hasil belajar matematika siswa SD Negeri 1 Petandakan. 
Penelitian lain yang dilakukan oleh Ida Purwati dengan judul "Penerapan Metode Pembelajaran Snowball Throwing disertai Diskusi dalam Pembelajaran Fisika Kelas VII di SMP Negeri 5 Candipuro". Hasil penelitian tersebut menyatakan bahwa terdapat perbedaan yang signifikan antara hasil pembelajaran fisika dengan menggunakan metode pembelajaran Snowball Throwing disertai diskusi dengan pembelajaran konvensional.

Berdasarkan uji hipotesis dan penelitian terdahulu dapat disimpulkan bahwa pembelajaran dengan menggunakan Snowball Throwing dapat meningkatkan hasil belajar matematika siswa kelas VII Mts Al Rosyid kendal Bojonegoro tahun ajaran 2015-2016.

\section{SIMPULAN DAN SARAN}

Berdasarkan analisis data dan pembahasan dapat disimpulkan bahwa: Ada pengaruh metode pembelajaran Snowball Throwing terhadap hasil belajar matematika pada pokok bahasan segitiga siswa kelas VII semester genap MTs Al Rosyid tahun pelajaran 2015-2016. Berdasarkan hasil penelitian ini peneliti sarankan 1). Metode pembelajaran Snowball Throwing perlu disosialisasikan agar dapat digunakan sebagai alternatif dalam meningkatkan hasil pembelajaran matematika di sekolah, 2). Sebaiknya metode pembelajaran Snowball Throwing dilaksanakan untuk kelas kecil (jumlah siswa antara 20-30 siswa) sehingga pembelajaran lebih efektif karena dengan ukuran kelas yang lebih kecil maka kontrol dan perhatian guru terhadap siswa dapat lebih optimal, 3). Perlu diadakan penelitian lanjutan sebagai pengembangan dari penelitian ini.

\section{DAFTAR RUJUKAN}

Asrori, M. 2010. Penggunaan Model Belajar Snowball Throwing dalam Meningkatkan Keaktifan Belajar. Jakarta: Rineka Cipta.

Budiyono. 2009. Statistika Untuk Penelitian Edisi Ke 2. Surakarta: Sebelas Maret University Press.

Depdiknas. 2004. Matematika Pembelajaran. Jakarta: Pusat Perbukuan Departemen Pendidikan Nasional.

Departemen Pendidikan Nasional. 2008. Kamus Besar Bahasa Indonesia. Jakarta:PT.Gramedia Pustaka Utama.

Hamdayama, J. 2014. Model dan Metode Pembelajaran Kreatif dan Berkarakter. Bogor: Ghalia Indonesia.

Lancarwati, V. 2012. Peningkatan Motivasi Belajar IPS Siswa Kelas VIII dengan menggunakan Metode Pembelajaran Snowball Throwing di SMP Negeri 4 Satu Atap Bawang Banjar Negara. Yogyakarta: UNY.

Ruslan, R. 2003. Metode Belajar dan Aplikasinya. Yogyakarta: Pustaka Pelajar.

Siporin, M. 1975. Hasil Belajar dan Prestasi Belajar. Jakarta: Rineka Cipta.

Sugiyono. 2007. Statistika Untuk Penelitian. Bandung: Alfabeta.

Suharsimi, A. 2007. Dasar-dasar Evaluasi Pendidikan. Jakarta: Bumi Aksara.

Suprijono, A. 2011. Pengertian Hasil Belajar. Yogyakarta: Pustaka Pelajar.

Suprijono, A. 2014. Cooperative Learning Teori \& Aplikasi PAIKEM. Yogyakarta: Pustaka Pelajar.

Margunayasa, L. 2012 Penerapan Metode Snowball Throwing Berbantuan Media Sederhana untuk Meningkatkan Hasil Belajar Matematika Siswa SD Negeri 1 Petandakan. Singaraja: UPG. 
